\title{
EVALUATION OF DROUGHT TOLERANCE OF SPRING WHEAT LINES IN THE FOREST-STEPPE OF UKRAINE
}

Demydov J. A., Khomenko S. O., Fedorenko I. V., Fedorenko M. V.

The V. M. Remeslo Myronivka Institute of Wheat of NAAS, Ukraine

The aim and tasks of the study envisaged assessing and identifying spring wheat lines of competitive variety trial by drought tolerance to be involved in research programs as starting material.

Material and methods. The study was conducted at the Laboratory of Spring Wheat Breeding of VM Remeslo Myronivka Institute of Wheat of NAAS of Ukraine in 2013-2014. Fifty five spring wheat lines of competitive variety trial were studied. Drought tolerance was evaluated in the field by the spike realization coefficient and in the laboratory by the seed germination percentage in sucrose solution as well as by electrolyte leakage.

Results and discussion. The meteorological conditions during the study period were contrast, which allowed evaluating and selecting breeding material by drought tolerance. Bread wheat lines of competitive variety trial Lutescens 10-36, Lutescens 11-24, Lutescens 12-30, Erythrospermum 13-11, Albidum 10-41, and others and durum wheat lines Leukurum 13-02, Melianopus 10-03, Leukurum 12-09, Leukurum 12-16, and Leukurum 12-41 were selected by the spike realization coefficient. Lines Melianopus 10-03, Leukurum 10-26, Lutescens 05-24, Lutescens 10-36, Lutescens 11-02, and Lutescens 12-26, and others were selected the seed germination percentage in sucrose solution. Lines Lutescens 10-36, Lutescens 05-24, Lutescens 10-23, Albidum 10-41, Melianopus 10-02, Leukurum 10-26, and others were selected by electrolyte leakage; their indices were much higher than those in standards.

Conclusions. Thus, in 2013-2014, the three methods of evaluation of drought tolerance selected spring lines that were the most drought tolerant: Lutescens 10-36 (submitted to the state variety trial as variety 'Oksamyt Myronivskyi'), Melianopus 10-02 (submitted to the state variety trial as variety 'MIP Raiduzhna'), Albidum 10-41, Leukurum 10-14, which are recommended as starting material in breeding for drought tolerance.

Key words:spring wheat, line, productivity, drought tolerance

УДК: 631.527:575:633.1

\section{ДОБІР ПШЕНИЧНО-ЖИТНХХ ХРОМОСОМНО ЗАМЩЕНИХ ФОРМ ТРИТИКАЛЕ ЗА НАЯВНІСТЮ МОРФОЛОГІЧНИХ ОЗНАК СПЕЛЬТИ}

Діордієва І. П., Рябовол Я. С.

Уманський національний університет садівництва, Україна

У статті обгрунтовано можливість відбору пшенично-житніх хромосомно заміщених форм тритикале за наявністю морфологічних ознак спельти. Показано, що при відборі хромосомно заміщених форм тритикале серед нащадків за наявністю ознак спельти, зникає потреба в аналізі всіх отриманих форм, оскільки контроль наявності хромосомного заміщення проводять тільки у тих нащадків, які мають ознаки спельти. В результаті досліджень відібрано зразок 116/14, у якого встановлено хромосомне заміщення.

Ключові слова: пшенично-житне хромосомне заміщення, тритикале, спельта, схрещування, морфологічна ознака.

(ㄱ І. П.Діордієва, Я. С. Рябовол. 2016.

ISSN 1026-9959. Селекція і насінництво. 2016. Випуск 110. 
Вступ.Тритикале - цінна сільськогосподарська культура, яка за врожайністю та багатьма цінними господарськими ознаками перевищує батьківські форми. Незважаючи на це, тритикале не займає належного місця в структурі посівних площ зернових культур, що пов'язано з низькою хлібопекарською якістю продукції $[1,2]$. Поліпшення хлібопекарських якостей та технологічних властивостей може зробити тритикале однією з найважливіших хлібних культур світу [3]. Створення та виділення пшенично-житніх хромосомно заміщених форм тритикале $\epsilon$ ефективним шляхом вирішення вищевказаних проблем $[4,5]$.

Аналіз літературних джерел, постановка проблеми. У геномному складі гексаплоїдних тритикале (Triticosecale Wittmack, $2 \mathrm{n}=6 \mathrm{x}=42$ ) присутні по сім пар хромосом геномів A, B та R. Хромосоми геномів A та B походять від пшениці, а хромосоми геному $\mathrm{R}-$ від жита. Такі тритикале називаються повнокомплектними, оскільки вони містять повні набори хромосом геномів батьківських форм. Крім цього, у тритикале виділяють хромосомно заміщені форми, в яких одна або декілька пар хромосом жита заміщено на гомеологічні їм пшеничні хромосоми [6, 7].

Особливий інтерес представляють заміщені лінії, що мають різні варіанти $\mathrm{R} / \mathrm{D}, \mathrm{R} / \mathrm{B}$, A/D, B/D заміщень, перші повідомлення про них з'явилися на початку 70-х pp. і грунтувалися на аналізі кон'югації хромосом за схрещування тритикале з телоцентриками, що несуть Dхромосоми [6]. Найбільш перспективними для селекційного поліпшення тритикале є заміщення $R / D$ типу. Такі заміщення забезпечують зміну тритикале за низкою цінних господарських ознак (висота рослин, вегетаційний період, хлібопекарські властивості тощо) [7].

Виникають пшенично-житні хромосомно заміщені форми тритикале внаслідокгібридизації гексаплоїдних тритикале з октоплоїднимиабо тетраплоїдними формами, а такожз гексаплоїднимивидами пшениць $[4,5]$. Одним із таких видів може бути пшениця спельта (Triticum spelta L., $2 \mathrm{n}=6 \mathrm{x}=42$ ), яка характеризується високим вмістом білка (до $25 \%$ ). За схрещуваннягексаплоїдних тритикале зі спельтою можуть виникати пшенично-житні хромосомно заміщені форми тритикале,які становлять практичний інтерес для селекційного поліпшення тритикале.

Ідентифікувати хромосомні заміщення у тритикале можна за допомогою кількох способів. Найчастіше з цією метою використовують методи C-бендінгу (диференціальне фарбування хромосом), FISH та GISH (цитогенетичні методи, які застосовують для визначення положення специфічної послідовності ДНК) та електрофорез запасних білків [8, 9]. Ці способи дозволяють ідентифікувати кожну хромосому жита та пшениці і встановити їх належність до конкретної гомеологічної групи [10]. Але, згідно з даними способами, для ідентифікації хромосомного заміщення необхідно провести дослідження всіх отриманих потомств. А щорічно тестувати все потомство, що було отримане в результаті схрещувань, за допомогою цитогенетичниго чи електрофоретичного аналізу - досить трудомісткий процес. Тому дані способи потребують значних затрат часу для виділення хромосомно заміщених форм.

Сукупність фенотипових або морфологічних ознак не дають можливості точно ідентифікувати хромосомне заміщення [11]. Однак, за наявністю або відсутністю певних ознак можна відбирати форми, в яких очікується хромосомне заміщення.При цьому контроль наявності хромосомного заміщення проводять лише серед відібраних форм. Таким чином спрощується процес добору хромосомно заміщених форм. Встановлення можливості добору пшенично-житніх хромосомно заміщених форм тритикале за фенотиповими чи морфологічними ознаками є актуальним.

Мета і задачі дослідження. Метою роботи було встановити можливість добору пшенично-житніх хромосомно заміщених форм тритикале за наявністю окремих морфологічних ознак спельти.

Виходячи з мети, було поставлено такі завдання: дослідити фенотиповий прояв морфологічних ознак спельти у форм тритикале, отриманих від схрещування тритикале та спельти; відібрати пшенично-житні хромосомно заміщені форми тритикале за наявністю деяких морфологічних ознак спельти. 
Матеріали і методика. Дослідженнязі створення та виділення пшенично-житніх хромосомно заміщених форм тритикале проводили на дослідному полі Уманського національного університету садівництва впродовж 2012-2016 pp. Матеріалом для створення пшенично-житніх хромосомно заміщених форм тритикале були сорти тритикале озимого Розівська 6, Розівська 7, Юнга, Ладне та пшениця спельта (Triticum spelta L.) Зоря України. Для створення пшенично-житніх хромосомно заміщених форм тритикале було проведено схрещування гексаплоїдних тритикале та спельти. В якості материнської форми використовували гексаплоїдні тритикале, в якості батьківської - пшеницю спельту. Схрещування проводили шляхом ручної кастрації материнської форми і запилення ії батьківською формою.

На наявність пшенично-житніх хромосомних заміщень аналізували потомство, отримане від схрещування гексаплоїдних тритикале із спельтою. Оцінку нащадків на наявність-відсутність морфологічних ознак спельти проводили протягом вегетації. Форми, які характеризувались наявністю морфологічних ознак спельти відбирали, як такі, що мають пшенично-житні хромосомні заміщення.

Перевіряли наявність пшенично-житніх хромосомних заміщень за допомогою «Способу відбору R/D заміщених форм тритикале» [12].Контроль наявності хромосомного заміщення проводили за допомогою гель-електрофорезу запасних білків зерна тритикале у відділі генетичних основ селекції СГІ-НЦНС НААН (Селекційно-генетичний інститут Національний центр насіннєзнавства і сортовивчення НААН).

Обговорення результатів. 3 метою створення пшенично-житніх хромосомнозаміщених форм тритикале було проведено схрещування гексаплоїдних тритикале (Triticosecale Wittmack, $A A B B R R$ )та спельти (Triticum spelta L., AABBDD). Отримані гібриди $\mathrm{F}_{1}$ характеризувались стерильністю колоса. Відмічено лише декілька випадків формування фертильних пилкових зерен. 3 метою підвищення рівня фертильності у гібридів першого покоління їх повторно схрещували з гексаплоїдними тритикале. У результаті було отримано частково фертильне потомство. Отримане потомство стабілізували шляхом самозапилення протягом кількох поколінь. Стабільними вважалися форми 3 високою фертильністю та озерненістю колоса.

Таким чином, було створенонизку нових генотипів, в яких очікувались пшеничножитні хромосомні заміщення. Із отриманого різноманіття для подальшого вивчення було відібрано 10 зразків, які характеризувалися проявом морфологічних ознак спельти (табл. 1).

Таблиця 1

Прояв ознак спельти у нащадків від схрещування тритикале та спельти

\begin{tabular}{|c|c|c|c|c|c|c|}
\hline \multirow[b]{2}{*}{ Селекційний зразок } & \multicolumn{6}{|c|}{ Ознака } \\
\hline & $\begin{array}{c}\text { Груба } \\
\text { (спельто- } \\
\text { їдна) коло- } \\
\text { скова луска }\end{array}$ & $\begin{array}{c}\text { Довгий } \\
\text { нещільний } \\
\text { колос }\end{array}$ & $\begin{array}{c}\text { Сланкий } \\
\text { кущ }\end{array}$ & $\begin{array}{c}\text { Восковий } \\
\text { наліт на } \\
\text { рослині }\end{array}$ & Безостість & $\begin{array}{l}\text { Високе } \\
\text { стебло }\end{array}$ \\
\hline $\begin{array}{ll}\text { Вихідна } & \text { Тривидові } \\
\text { тритикале }\end{array}$ & - & - & - & + & - & + \\
\hline форма Спельта & + & + & + & - & + & + \\
\hline $116 / 14$ & - & - & - & + & + & + \\
\hline $148 / 14$ & + & - & - & + & - & + \\
\hline $169 / 14$ & + & - & + & + & - & + \\
\hline $181 / 14$ & - & + & - & - & - & + \\
\hline $220 / 14$ & - & + & - & - & - & + \\
\hline $259 / 14$ & + & - & + & + & - & + \\
\hline $320 / 14$ & - & + & - & + & - & + \\
\hline $361 / 14$ & - & - & + & - & - & + \\
\hline $421 / 14$ & - & - & + & - & - & + \\
\hline $474 / 14$ & - & - & - & - & - & - \\
\hline
\end{tabular}

Примітка. «+» наявність ознаки, «-» відсутність ознаки 
Для рослин пшениці спельти характерним є наявність безостого довгого рихлого колоса $з$ грубою колосковою лускою, прямостоячого куща та високого стебла без воскового нальоту. Для рослин тривидових тритикале притаманні остистий колос середньої довжини з нормальною колосковою лускою, розлогий тип куща та високе стебло з восковим нальотом.

Груба (спельтоїдна) колоскова луска, що $є$ не характерною для тритикале, була у зразків 148/14, 169/14 та 259/14. Наявність довгого нещільного, як у спельти, колосу характеризувалися зразки 181/14, 220/14 та 320/14. Прямостоячим типом куща (домінантна ознака тритикале «розлогий кущ») вирізнялися зразки 169/14, 259/14, 361/14 та 421/14. У зразків 181/14, 220/14, 361/14, 421/14 та 474/14 була відсутня типова для тритикале ознака - наявність «воскового нальоту на рослинах».

Дуже вкороченими відносно колоса остюками характеризувався зразок 116/14. Відповідно у цього зразка не проявлялась типова ознака тритикале «остистий колос». У пшениці ознака «безостість» є домінантною. За створення тритикале отримуємо остисті форми, незалежно від того, яка пшениця (остиста чи безоста) використовувалась для схрещувань. Це пов'язано з тим, що сильна експресія генів остистості жита пригнічує прояв генів безостості пшениці. Ген остистості жита локалізований в хромосомі $1 \mathrm{R}$ [13]. Тому формування дуже вкорочених остюків у цього зразка може бути пов'язанозіструктурними перебудовами хромосоми $1 \mathrm{R}$.

Зразок 474/14 характеризувався відсутністю типової для обох вихідних форм ознаки «високе стебло». Даний зразок був карликовим (висота рослин $56 \mathrm{cm).} \mathrm{Це} \mathrm{може} \mathrm{бути}$ пов'язано із наявністю хромосомних заміщень. Адже встановлено, що хромосомне заміщення 2R/2D обумовлює зниження висоти рослин тритикале [14].

Селекційні зразки 116/14, 148/14, 169/14, 181/14, 220/14, 259/14, 320/14, 361/14, 421/14 та 474/14 було відібрано для аналізу як такі, в яких очікуються пшенично-житні хромосомні заміщення.

Для контролю наявності пшенично-житнього хромосомного заміщення проводили схрещування тритикале з відомою геномною формулою з тритикале, в яких очікуються пшенично-житні хромосомні заміщення, і за стерильністю гібридів відбирали пшеничножитні хромосомно заміщені форми тритикале.

За схрещування тритикале сорту Наварро з відомою геномною формулою із зразками 148/14, 169/14, 181/14, 220/14, 259/14, 320/14, 361/14, 421/14 та 474/14 потомство було фертильним. Це пояснюється відсутністю у цих зразків хромосомних перебудов. У результаті гібридизації тритикале сорту Наварро із зразком 116/14 було отримано стерильне потомство. Це доводить наявність пшенично-житнього хромосомного заміщення у даного зразка.

Таким чином, було створено і відібрано зразок чотиривидового тритикале $116 / 14$, в якого є пшенично-житнє хромосомне заміщення. Було проведено гель-електорофорез спектру запасних білків зерна даного зразка,у результаті чого було підтверджено наявність пшенично-житнього хромосомного заміщення у зразка 116/14.

За добору пшенично-житніх хромосомно заміщених форм тритикале серед потомств за наявністю ознак спельти зникає потреба в аналізі всіх отриманих форм за допомогою цитогенетичних методів, так як контроль наявності хромосомного заміщення проводять тільки у тих потомств, що характеризуються фенотиповим проявом морфологічних ознак спельти. Це значно зменшує обсяги робіт і скорочує затрати часу на виділення форм із хромосомним заміщенням.

У результаті проведених досліджень розроблено «Спосіб створення та відбору повністю або частково пшенично-житніх хромосомно заміщених форм тритикале» і отримано патент України на корисну модель [15].

Висновки. Встановлено можливість відбору пшенично-житніх хромосомно заміщених форм тритикале за наявністю ознак спельти. Проте, необхідно проводити контроль наявності хромосомного заміщення у відібраних форм. 
Виділено селекційний зразок 116/14, в якого є пшенично-житнє хромосомне заміщення.

\section{Список використаних джерел:}

1. Щипак Г. В. Селекція і насінництво тритикале озимого // Спеціальна селекція і насінництво польових культур. Харків, 2010. С. 70-107.

2. Гребенюк I. В. Методи збагачення генофонду тритикале // Вісник ЛНУ ім. Тараса Шевченка. 2010. № 15. С. 100-117.

3. Васильченко А. Н. Проблемы качества зерна для хлебопечения // Хранение и переработка зерна. 2006. №5(83). С. 43-44.

4. Діордієва І. П. Створення та оцінка чотиривидових тритикале: автореф. дис... канд. с.г. наук: спец. 06.01.05 селекція і насінництво. Умань, 2015. 24 с.

5. Хомякова О. В. Создание исходного материала для селекции тритикале на основе клеточных биотехнологий: автореф. дис... канд. біол. наук: спец. 06.01.05. селекція і насінництво. Саратов, 2009. 21 с.

6. Gustafson J. P., Lukaszewski A. J., Robertsjn K. Chromosome substitutions and modifications in hexaploitriticale: a re-evaluation // Genetics and Breeding of Triticale. EUCARPIA meeting. Clermont-Ferrand, 1984. P. 15-27.

7. Куркиев У. К., Куркиев К. У., Абдулаева А. К. Создание гексаплоидных тритикале с хромосомами генома D // Роль тритикале в стабилизации и увеличении производства зерна и кормов: материалы Междунар. науч.-практконф. Ростов-на-Дону, 2010. С. 34-41.

8. GillB. S., KimberG. The GiemsaC-banding and evaluation of wheat // Proc. Natl. Acad. Sci. USA. V. 1. 1974. P. 4086-4090.

9. Дубовец Н. И., Сычева Е. А., Соловей Л. А., Штык Т. И., Бондаревич Е. Б. Создание коллекции хромосомно-замещенных линий гексаплоидных тритикале и ее использование в практической селекции и цитогенетических исследованиях // Проблеми і досягнення генетики, селекції та біотехнології. К.: Логос, 2012. С. 55-59.

10. Gill R. S., Bains N. S., Dhindsa G. S. Characterization of D/R chromosome segregant lines from triticale $\times$ bread wheat crosses using chromosome specific SSR markers // Wheat Information Service. 2010. №110. P. 19-23.

11. Lukaszewski A. J. Cytogenetically engineered rye chromosomes $1 \mathrm{R}$ to improve bread making quality of hexaploid triticale // Crop Sci. CropBreeding\&Genetics. 2006. №8. C. 2183-2194.

12. Пат. №89585 Україна. Спосіб відбору R/D заміщених форм тритикале / Ф. М. Парій, М. Ф. Парій, І. П. Діордієва, І. Р. Заболотна, Я. С. Рябовол, В. В. Любич (Україна); заявл. 29.11.13.; опубл. 25.04.14; бюл. №8.

13. Wang E. M., Jing J. K.,Wang X., WenY. X. Genetic variation of rye chromosome $1 \mathrm{R}$ in wheat background // Ada Cenctioo Sinioo (in Chinese). 1997. № 24. P. 42.

14. Куркиев К. У. Генетические аспекты селекции короткостебельных гексаплоидных тритикале: автореф. дис... д. б. н.: спец. 03.00.15, 06.01.05 генетика,селекция и семеноводство. Дербент, 2009. 24 с.

15. Пат. № 101705 Україна. Спосіб створення і відбору повністю та/або частково пшенично-житніх хромосомно заміщених форм тритикале / І.П. Діордієва, О. І. Рибалка, Ф.М. Парій, М.Ф. Парій, Я.Ф. Парій, Я.С. Рябовол, І.Р. Заболотна, О. В. Єщенко, В.В. Любич (Україна); заявл. 06.04.2015.; опубл. 25.09.2015.; бюл. № 18.

\section{References}

1. Schypak GV.Breeding and seed production of triticale. Special breeding and seed production of winter triticale. Kharkiv, 2010. P. 70-107.

2. Grebeniuk IV. Methods of enriching of the triticale gene pool. Bulletin of LNU them. Taras Shevchenko. 2010; 15: 100-117.

3. Vasylchenko AN. Grain quality problems for bakery. Storage and processing of grain. 2006; 5 (83): 43-44. 
4. Diordiieva IP. Creation and evaluation of four species triticale forms. [authoabstract of dissertation]. UNUH, 2015.

5. Khomiakova OV. Creation of initial material for triticale breeding basic on cell biotechnology. [authoabstract of dissertation]. Saratov: SNAU, 2009.

6. Gustafson JP, Lukaszewski AJ, Robertsjn K, Chromosome substitutions and modifications in hexaploid triticale: a re-evaluation. Genetics and breeding of triticale: EUCARPIA meeting: Clermont-Ferrand, 1984. P. 15-27.

7. Kurkiev YK, Kurkiev KY, Abdulaieva AK. Creation of hexaploid triticale with genome D chromosomes. Proceedings from Triticale role in the stabilization and increase of grain and feed '10: - International scientific-practical conference. Rostov-na-Dony, 2010. P. 34-41.

8. Gil ,BS, Kimber G. The Giemsa C-banding and evaluation of wheat. Proc. Natl. Acad. Sci. USA, 1974. P. 4086-4090.

9. Dubovets NI, Sucheva EA, Solovey LA, Shtyk TI, Bondarevich EB. Creation of chromosome substituted lines of triticale collection and her using in practical breeding and cytogenetics researches. Problems and advances in genetics, breeding and biotechnology. Kyiv: Logos, 2012. P. 55-59.

10. Gill RS, Bains NS, Dhindsa GS. Characterization of D/R chromosome segregant lines from triticale $\times$ bread wheat crosses using chromosome specific SSR markers. Wheat Information Service, 2010. P. 19-23.

11. Lukaszewski AJ. Cytogenetically engineered rye chromosomes 1R to improve bread making quality of hexaploid triticale. Crop Sci. CropBreeding\&Genetics. 2006. P. 2183-2194.

12. Wang EM, Jing JK, Wang X, Wen YX. Genetic variation of rye chromosome $1 \mathrm{R}$ in wheat background. Ada Cenctioo Sinioo, 1997. 42 p.

13. Kurkiev KY. Genetics aspects of shorts traw hexaploid triticale breeding. [authoabstract of dissertation]. Derbent, 2009.

14. Pariy FM, Pariy MF, Diordiieva IP, Zabolotna IR, Riabovol Y S, Liubych VV. The method of selection R/D substituted forms of triticale. Patent UA, №89585, 2014.

15. Diordiieva IP, Rybalka OI, Pariy FM, Pariy MF, Pariy YaF, Zabolotna IR, Riabovol YaS, Eschenko OV, Liubych VV. The method of creation and selection fully and/or partially wheat-rye chromosome substitution forms of triticale. Patent UA, №101705, 2015.

\section{ОТБОР ПШЕНИЧНО-РЖАНЫХ ХРОМОСОМНО ЗАМЕЩЕННЫХ ФОРМ ТРИТИКАЛЕ ПО НАЛИЧИЮ МОРФОЛОГИЧЕСКИХ ПРИЗНАКОВ СПЕЛЬТЫ}

Диордиева И. П., Рябовол Я. С.

Уманский национальный университет садоводства, Украина

Цель и задачи исследований. Целью работы было установить возможность отбора пшенично-ржаных хромосомно замещенных форм тритикале по наличию отдельных морфологических признаков спельты.

Исходя из цели, были поставлены следующие задачи: исследовать фенотипическое проявление морфологических признаков спельты у форм тритикале, полученных от скрещивания тритикале и спельты; отобрать пшенично-ржаные хромосомно замещенные формы тритикале по наличию некоторых морфологических признаков спельты.

Материал и методика. Исследования по созданию и выделению пшенично-ржаных хромосомно замещенных форм тритикале проводили на опытном поле Уманского национального университета садоводства в течение 2012-2016 гг. Материалом для создания пшенично-ржаных хромосомно замещенных форм тритикале были сорта тритикале озимой Розовская 6, Розовская 7, Юнга, Ладное и пшеница спельта (Triticum spelta L.) сорт Заря Украины.

Обсуждение результатов. В результатескрещивания тритикале и пшеницы спельты было получено потомство, в котором ожидалось наличие пшенично-ржаных хромосомных замещений. Из него для дальнейшего изучения отобрали 10 образцов, характеризовав- 
шихся проявлением морфологических признаков спельты (грубая колосковая чешуя, длинный рыхлый колос, прямостоящий куст, отсутствие воскового налета на растении, безостость, высокий стебель). Был проведен контроль наличия хромосомного замещения у всех отобранных образцов. Его присутствие обнаружено у образца 116/14. Гельэлектрофорез запасных белков зерна образца 116/14 подтвердил наличие у него пшенично-ржаного хромосомного замещения.

Выводы. Установлена возможность отбора пшенично-ржаных хромосомно замещенных форм тритикале при наличии признаков спельты. Однако, необходимо проводить контроль наличия хромосомного замещения у отобранных форм.

Выделен селекционный образец 116/14, у которого есть пшенично-ржаное хромосомное замещение.

Ключевые слова: пшенично-ржаные хромосомные замещения, тритикале, спельта, скрещивание, морфологические признаки

\section{SELECTION OF WHEAT-RYE CHROMOSOME SUBSTITUTED TRITICALE FORMS BY PRESENNCE OF SPELT MORPHOLOGICAL TRAITS}

Diordieva I. P., Riabovol Ya. S.

Uman National University of Horticulture, Ukraine

The aim and tasks of the study. The research purpose was to estimate a possibility of selecting wheat-rye chromosome substituted triticale forms by presence of certain spelt morphological traits.

Proceeding from the purpose, the following objectives were set: to investigate phenotypic expression of spelt morphological traits in forms obtained by crossing triticale and spelt; to select wheat-rye chromosome substituted triticale forms by presence of some morphological traits of spelt.

Materials and methods. Wheat-rye chromosome substituted triticale forms were created and selected in the experimental filed of Uman National University of Horticulture in 2012-2016. Winter triticale varieties 'Rozovska 6', 'Rozovska 7', 'Yunha', and 'Ladne' as well as spelt (Triticum spelta L.) variety 'Zaria Ukrainy' were taken as materials for creating wheat-rye chromosome substituted forms.

Results and discussion. Hybridization between triticale and spelt resulted in progeny, in which wheat-rye chromosome substitutions were expected. For further studies, 10 accessions with spelt morphological traits (rough chaff, loose spike, erect bush, no wax bloom on plants, awnlessness, and tall stem) were selected. Chromosome substitution was monitored in all selected accessions. It was detected in accession 116/14. Gel electrophoresis of storage proteins from 116/14 grain confirmed wheat-rye chromosome substitution.

Conclusions. We demonstrated a possibility of selection of wheat-rye chromosome substituted triticale forms provided there are spelt traits. However, it is necessary to monitor selected forms for chromosome substitution.

Breeding accession 116/14 carrying a wheat-rye chromosome substitution was selected.

Key words: wheat-rye chromosome substitution, triticale, spelt, hybridization, morphological traits 